\title{
Measuring the Success Metric for Effective Succession Planning: The Conceptual Perspective
}

\author{
Muhamad Tasyrif Ghazali \\ Faculty of Business \& Management \\ Universiti Sultan Zainal Abidin, 21300 Terengganu, Malaysia \\ Mazuri Abd. Ghani (Corresponding author) \\ Faculty of Business \& Management \\ Universiti Sultan Zainal Abidin, 21300 Terengganu, Malaysia \\ Syamsul Azri Abdul Rahman \\ Faculty of Business \& Management \\ Universiti Sultan Zainal Abidin, 21300 Terengganu, Malaysia
}

Received: Dec. 25, 2021 Accepted: Jan. 26, 2022 Online published: Feb. 16, 2022

doi:10.5296/ijhrs.v12i1.19371ＵRL: https://doi.org/10.5296/ijhrs.v12i1.19371

\begin{abstract}
This conceptual study aims to explore the evolution of succession planning by focusing on a systematic procedure and highlighting the instrument of success metric that influences succession planning effectiveness. There are several approaches to discuss the succession planning process and the effectiveness of the used methods. However, no single systematic process applies to the entire organization. Besides that, this research includes a literature review, focusing on key success metrics of succession planning. The metrics used to track succession planning effectiveness should be directly related to the organization's strategic goal. Therefore, the metrics must be clearly defined and articulated as part of the organization's formal succession plan. This study reveals three key success metrics of succession planning: (1) bench strength, (2) time-to-fill, and (3) talent turnover. A good success metric indication will allow a company to analyze the impact of a succession plan in retaining talent in the pipeline as a proactive strategy.
\end{abstract}

Keywords: Succession Planning Process, Success Metric, Leadership, Talent Pool.

\section{Introduction}

\subsection{Research Background}

Filling vital executive leadership positions with qualified and motivated candidates is not an 
easy task for many organizations (Chang \& Besel, 2020). One of the issues facing business organizations these days is producing a leader from within the organization's talent pool who can fit into a set of duties and procedures for the next level of leadership (Aboradi \& Masari, 2018; Jackson \& Dunn-Jensen, 2021). Succession planning is a technique for ensuring that the company has a plan in place to ensure that the organization's continuity is maintained when the executive director, senior managers, or talented people leave. Succession planning is not about crowning the next CEO before the right time but building a systematic process, which involves the board and senior management in the discussion (Aboradi \& Masari, 2018). systematic and long-term practice of succession planning will ensure that an organization has the necessary pool of talent to enable it to meet its business objectives and achieve its mission (Rothwell, 2016). In some instances, the plan could be considered invalid when a person who has been identified as a successor fails to live up to the expectation or resigns unexpectedly.

Effective succession planning helps boost the confidence and understand each employee's purpose and what drives them to achieve business goals. A systematic process of succession plans was most effective when it was designed within an evaluation framework, education, and growth plans in order to measure progress and success, as well as provide any evidence to support changes to the succession planning process and leadership development (Abdellah, 2021). This systematic process also has an impact on the organization's succession plan, which aims to create future leaders. As a result, the idea of a structured succession planning process in which leaders are categorized according to an internal definition of future potential and placed on bench lists for certain tasks has emerged. In line with the organization's objectives, the succession planning process has also been improved, including the family business, SMEs, non-profit organizations, education, and the private sector. Various succession planning processes have been established, but the most essential element is measuring the effectiveness and outcomes. The element of measuring effectiveness is very much related to the scope of the succession planning success metrics. The succession planning process primarily focuses on identification and development, with little attention paid to the evaluation phase, particularly in terms of success metric measure.

\subsection{Succession Planning Has Changed and Evolved Over Time}

The concept of succession planning is undergoing changes in today's increasingly dynamic organizations. Many organizations constantly go through restructuring, reorganization, and business strategy changes. This research shows how succession planning has evolved, from the 1950s to the 2010s. Henri Fayol introduced succession planning in 1916, believing that if the succession plan is disrupted, the organization would not make the necessary transition (Rothwell, 2016). Henri published Administration Industrielle et Générale in 1916, in which he developed 14 management principles. These concepts, which were first defined in the early twentieth century and are still commonly held today, indicate that management is responsible for ensuring the "stability of tenure of personnel. If that need is not met, Henri believes that crucial roles will be filled by people who are not prepared.

Kesner \& Sebora (1994) explored three stages of the succession planning phase. The first phase spanned the decades of the 1950s and 1960s. The beginning of scope research can be 
regarded as the early development between the 1950s and 1960s. Next, the focus on succession planning is then expanded in the context of theory development to emphasize the importance of succession planning in organizations, as well as the discovery of finding through empirical study among researchers to support the relationship to existing theories. This change happened during phase 2 in the 1970s. Review and explosive growth characterize the final period, which ran in the 1980s. Next, the early 2000s involved the change from technology - based employment planning to a focus on manpower towards a more comprehensive human resources planning strategy (Jackson \& Dunn-Jensen, 2021; Parfitt, 2017).

\subsubsection{The 1950s-1960s: The Emergence of Succession Planning}

The origins of succession planning have been extensively debated in academic research. Throughout the 1960s, Grusky explained a number of critical concerns about the subject. Grusky (1960) was a pioneer in identifying essential aspects in succession planning, designing a research study approach. During the 1950s to 1960s, research focused on the origin of the successor and the frequency of succession to ensure that both criteria had a substantial impact on the succession plan's implementation. At the same time, the study was also expanded comprehensively by identifying the characteristics of succession required in holding strategic positions and grouped in talent clusters. Similarly, emphasis is given to the role of the board in supporting and influencing the implementation of the succession plan. Furthermore, instead of focusing just on the causes and consequences of succession planning, academics in another scenario began to explore the equally important aspects of decision-making and the development of succession frameworks and typologies (Kesner \& Sebora, 1994).

\subsubsection{Succession Planning in the 1970s: Theory Development and Empirical Research}

Due to numerous difficulties and needs of the organization, the scope of succession planning studies grew and expanded by the 1970s. Research not only focused on the succession plan's origins and administrative framework but also the overall implementation process. Redlich (1977) and Greenblatt (1978) demonstrated the existence of studies with a broader scope by focusing on processes and identifying and outlining the steps of succession plans that must exist for them to be implemented in organizations (Kesner \& Sebora, 1994). The study also discovered that the stages in the process of succession plan implementation vary in quantity and that a standard cannot be established; however, both studies reveal that the stages remained consistent in type.

\subsubsection{In the 1980s: Review and Rapid Expansion Describe the Succession Planning Process}

The 1980s was an era of reflection among succession planning researchers. The study of succession plans has evolved into strategic planning integration, which takes into account future change expectations. Gordon \& Rosen (1981) discovered aspects such as pre-arrival factors, which include the fit of the successor's characteristics with the post, as well as the skill and work experience in managing the organization. Post-arrival factors primarily concentrate on the process of observation and monitoring, both of which are components for 
future succession plan studies' adaptation. Kohler \& Strauss (1983) also briefly surveyed the literature on succession planning. The necessity for enhanced term clarity was one of their main recommendations. The authors also argued that succession might not be a straight line. To put it another way, the succession process may flow easily from one step to the next.

\subsubsection{In the 2000s: Integrated Succession Planning to Human Resources Planning Strategy}

In the 2000s, the concept of succession planning has evolved, involving changing from technology based employment planning to a focus on manpower towards a more comprehensive human resources planning strategy (Barr, 2019; Jackson \& Dunn-Jensen, 2021; Parfitt, 2017). However, the core components continue to be present although the focus on succession planning has changed over time (Chavez, 2011). Furthermore, the alignment of a development plan with a succession plan seen as signals a move away from the previous succession system's "replacement" approach and toward a methodical strategy that focuses on long-term planning to nurture and develop future leaders. The emphasis on this component of integrated development will highlight the organization's efforts to develop competent people by purposefully placing someone in their position, or 'the right person for the right job' (Conger \& Fulmer, 2004).

\subsection{Definition of Succession Planning}

It is challenging to find a standard and generally accepted succession planning definition. A diversity of definitions of succession is important because it allows us to distinguish the various types of succession and identify the roles in succession planning. In the literature, interchangeable words are used to describe succession planning for an organization in various contexts and scenarios. Alternative terms include leadership development, talent management, leadership continuity planning, replacement planning, and career development (Carriere et al., 2009; Crumpacker \& Crumpacker, 2007; Song \& Thompson, 2011). Thus, this situation gives rise to the ambiguity of the succession planning concept due to the inconsistencies and standards of terms agreed in the literature.

Succession planning is defined as a systematic process in which individuals are matched to critical positions with continual development and growth plan of employees in order to ensure that key positions maintain some level of stability, thus enabling an organization to achieve business objectives (Atwood, 2007; Calareso, 2013; Rothwell, 2016). Moreover, there is a discussion about how critical positions are described in succession planning, with some organizations focusing primarily on top positions. Meanwhile, some argue that the focus of the succession planning should also include the provision of middle management and supervisory level positions as part of a more comprehensive long-term strategy for sustained leadership development (Berchelmann, 2005; Berke, 2005; Calareso, 2013; Rothwell, 2016).

According to Orellano \& Miller (1997) defined succession planning as identifying critical management positions within the organization, identifying future vacancies in those positions, and identifying managers who would potentially fit into these vacancies. In addition, Garman $\&$ Practice (2004) defined succession planning as a structured process involving identifying 
and preparing a potential successor to assume a new role. By "structured," they refer to a process with some reliable structure and/or custom, thereby excluding from the definition the more ad hoc or "just-in-time" identification of successors. The "identification and preparation" component of the definition is purposely left undefined in terms of specific methods in order to reflect the full heterogeneity of current practice.

A prominent researcher in succession planning, Rothwell (2005), define succession planning as an organizational, systematic, and deliberate effort to ensure leadership continuity in key positions, retain and develop knowledge capital and intellectual for the future, and encourage people for development. In the late 2000s, various authors have developed the definition of succession planning. Succession planning is a systematic, proactive, and ongoing process. Table 2 lists a detailed breakdown of the essential elements in succession planning.

Table 2. Major elements used to define succession planning

\begin{tabular}{|c|c|c|}
\hline The Main Definition Elements & The Elements & References \\
\hline \multirow[t]{6}{*}{$\begin{array}{l}\text { Succession Planning is a } \\
\text { process }\end{array}$} & Process/activities & $\begin{array}{l}\text { Noe et al. (2000), Huang (2001), } \\
\text { Conger \& Fulmer (2003), Runestad } \\
\text { (2014) }\end{array}$ \\
\hline & Proactive process & $\begin{array}{l}\text { Collins and Collins (2007), Gabour } \\
\text { Atwood (2007), Rothwell (2016), } \\
\text { Fink \& Brayman (2006), Zepeda et } \\
\text { al., (2012) }\end{array}$ \\
\hline & Systematic process & $\begin{array}{l}\text { Garman and Glawe (2004), Rothwell } \\
\text { (2010), Adewale et al. (2011), Kim } \\
\text { (2012), Davis (2019) }\end{array}$ \\
\hline & Deliberate/intentional process & $\begin{array}{l}\text { Rothwell (2010), Kim (2012), } \\
\text { Weisblat (2018) }\end{array}$ \\
\hline & Ongoing process & Dessler (2020), Atwood (2020) \\
\hline & $\begin{array}{l}\text { Forecasting/long term view } \\
\text { process }\end{array}$ & Luna (2012), Davis (2017) \\
\hline \multirow[t]{6}{*}{ Identifying position } & Key positions & Rothwell (2016) \\
\hline & Key leadership positions & Darvish and Zahra (2014) \\
\hline & $\begin{array}{l}\text { Critical management } \\
\text { positions }\end{array}$ & Orellano \& Miller (1997) \\
\hline & Key roles & Conger \& Fulmer (2003) \\
\hline & $\begin{array}{l}\text { Key managerial or } \\
\text { professional positions }\end{array}$ & Adewale et al. (2011) \\
\hline & Key players & Noe et al. (2000) \\
\hline \multirow[t]{3}{*}{$\begin{array}{l}\text { For identifying, developing } \\
\text { people }\end{array}$} & $\begin{array}{l}\text { Identifying, developing, and } \\
\text { retaining }\end{array}$ & Davis (2017) \\
\hline & $\begin{array}{l}\text { Mentoring, coaching, and } \\
\text { grooming }\end{array}$ & Kim (2012) \\
\hline & Knowledge transfer & Buckway (2020) \\
\hline
\end{tabular}


To fill in the vacancies

\begin{tabular}{|l|l|} 
Fill in the vacancies & Kim (2012) \\
\hline Potentially fit into vacancy & Orellano \& Miller (1997) \\
\hline Replace key players & Noe et al. (2000) \\
\hline $\begin{array}{l}\text { Ready to move/preparing into } \\
\text { those roles. }\end{array}$ & Atwood (2020) \\
\hline
\end{tabular}

This study also discovered that the succession planning can improve the predictability of people analytics by recognizing internal talent within organizations that are highly motivated and well suited for critical position.. Succession planning also assists and develops people professionally so that they can be candidates for future leadership positions, ensuring that organizational performance remains stable and that there are no organizational problems that might be caused by the sudden vacancy of the key position in the organization.

\section{Methodology}

This research reviews the literature primarily related to revolution in the history of succession planning, systematic process, and succession metric instrument in measuring the effectiveness of succession planning. The literature has been divided into an evolution stages, various definitions of succession planning and systematic process of succession planning. This review also covers performance indicators in success metric consisting of (1) bench strength, (2) time to fill, and (3) talent turnover.

\section{Process of Succession Planning}

Succession planning is a process that not only ensures the stability and tenure of key personnel but is also perhaps best defined as any effort to ensure the continued effective performance of an organization, division, department, or workgroup by providing for the development, replacement, and strategic application of key people over time (Ali et al., 2019; Rothwell, 2016). The main purpose is to have a pool of qualified candidates for the key position. Implementing an effective succession plan requires a systematic process (Badawy et al., 2016; Morrin, 2013). This systematic process distinguishes succession planning from replacement planning. An effective plan process will result in quality leadership. Effective leadership in key positions is critical to the success of any organization. According to Khanaman et al.(2020), meaningful positive relations between each decision-making style and organizational structure become stronger and more effective when strategic succession planning in action mediates their relation, confirming the assumption that operating the succession planning can strengthen the relations within the organization.

For a long time, the succession plan process has always changed, whether due to environmental factors, direction, organizational culture, structure, or demographics of employees. Kesner \& Sebora (1994) explained the succession model development regarding process issues in succession plans. The process of succession can be interpreted by two aspects: (a) the process models (Handler, 1990; Longenecker \& Schoen, 1978) and (b) the lifecycle models (Barnes \& Hershon, 1976; Bogdány et al., 2014; Gersick et al., 1997; Greiner, 1998). The process models construe the succession process as a periodic process. The life cycle models interpret the succession process as a way of organizational evolution 
finalized with business transfer. Organizations could create and sustain high bench strength by moving beyond succession planning as a process of updating a list. A systematic process based on the integration of leadership development frameworks and succession plans is considered as a way to take a long-term view by designing individual development plans for developing and managing talent throughout the organization (Conger \& Fulmer, 2004; Groves, 2007). The main categories related to succession planning are examined herein, and we summarize the different models proposed for the matrix of succession planning in organizations, the succession planning process are presented in Table 3.

Table 3. The Matrix of Succession Planning Process

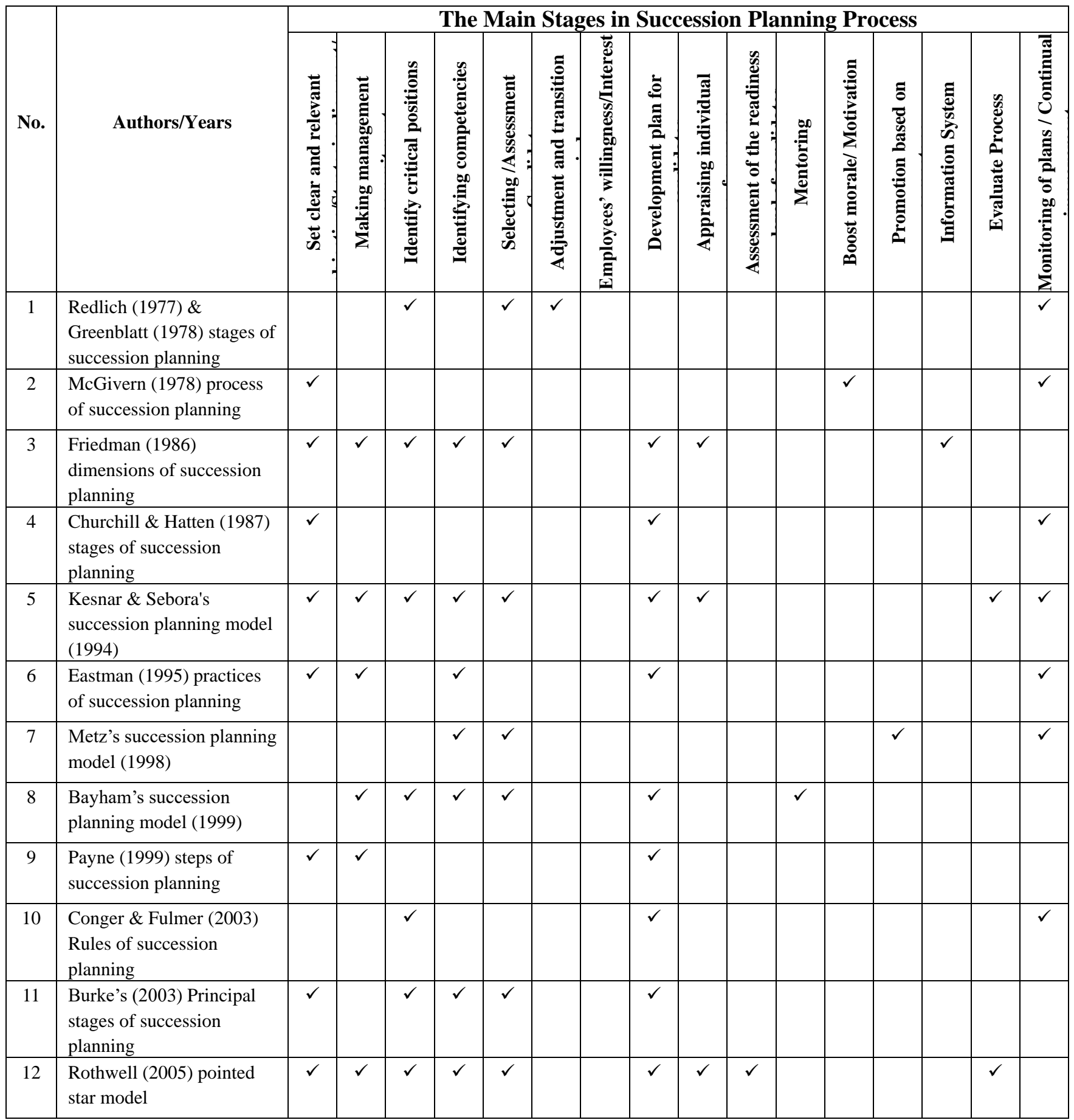




\begin{tabular}{|c|c|c|c|c|c|c|c|c|c|c|c|c|c|c|}
\hline 13 & $\begin{array}{l}\text { Harrison, McKinnon \& } \\
\text { Terry succession planning } \\
\text { model (2006) }\end{array}$ & & & & $\checkmark$ & $\checkmark$ & $\checkmark$ & $\checkmark$ & $\checkmark$ & & & & $\checkmark$ & $\checkmark$ \\
\hline 14 & $\begin{array}{l}\text { Gandossy \& Verma (2006) } \\
\text { cornerstones of succession } \\
\text { planning }\end{array}$ & $\checkmark$ & $\checkmark$ & $\checkmark$ & & $\checkmark$ & & $\checkmark$ & & & & & & $\checkmark$ \\
\hline 15 & $\begin{array}{l}\text { Kim's succession planning } \\
\text { model (2006) }\end{array}$ & $\checkmark$ & & & & $\checkmark$ & & $\checkmark$ & & & & $\checkmark$ & & \\
\hline 16 & $\begin{array}{l}\text { Charan's succession } \\
\text { planning model (2006) }\end{array}$ & & & & $\checkmark$ & & & & & & & & & $\checkmark$ \\
\hline 17 & $\begin{array}{l}\text { Rubin, Powers \& Illia } \\
\text { (2007) Basic Steps of } \\
\text { succession planning }\end{array}$ & & & $\checkmark$ & $\checkmark$ & $\checkmark$ & & $\checkmark$ & & $\checkmark$ & & & & $\checkmark$ \\
\hline 18 & Jarrell \& Pewitt (2007) & $\checkmark$ & & & & $\checkmark$ & & $\checkmark$ & & & & & $\checkmark$ & \\
\hline 19 & $\begin{array}{l}\text { Grove's succession } \\
\text { planning model (2007) }\end{array}$ & & & & & $\checkmark$ & & $\checkmark$ & & $\checkmark$ & & & & \\
\hline 20 & $\begin{array}{l}\text { Human Resource } \\
\text { Management,SHRM(2009) }\end{array}$ & $\checkmark$ & & & $\checkmark$ & & & $\checkmark$ & & & $\checkmark$ & & & \\
\hline 21 & $\begin{array}{l}\text { Riddick's succession } \\
\text { planning model (2009) }\end{array}$ & $\checkmark$ & & & & $\checkmark$ & & $\checkmark$ & & & & & $\checkmark$ & \\
\hline
\end{tabular}

\section{Success Metric of Succession Planning}

A succession planning success metric is a tool or mechanism for evaluating the implementation of a succession plan. Numerous processes of succession plan efficacy are applied in theory and business practice, depending on the direction, organizational environment, and support systems that exist. Success metric is relatively reflected to the evaluation process of succession planning, in addition to tracking success indicators on a regular basis, identifying candidates' degrees of advancement, and using a variety of evaluation techniques to correctly expose the reality of succession planning progress.

In order to ensure continual progress, the review process at each level in succession planning should be continuous and comprehensive, with a primary focus on evaluation instruments; these are all necessary to accurately expose the reality of succession planning progress (Abdellah, 2021). When it comes to succession planning, organizations can look at multiple factors to assess their outcomes. Succession planning's success depends on many factors such as well-planned design, resource allocation, careful implementation process, credibility of staff, and commitment of top-level management (Huang, 2001). Some organizations look at the number of candidates in their pipelines, while others track retention rates for their succession candidates. Ultimately, there is no one set of metrics that is commonly used. In fact, the studies revealed a concerning lack of measurements metric in succession planning. Hence, this study focuses on three key success metric succession plans based on (Rothwell, 2016), (Fahr UAE, 2017), and (Pandey \& Sharma, 2014). The success metric of succession planning is presented in Table 4. 


\subsection{Bench Strength}

The organization's ability to quickly find skilled and well-suited internal talent to immediately fill the crucial positions is referred to as bench strength (Riddick, 2009). Whenever an incumbent leaves a critical position, whether in leadership, management, or operations, the organization should have a successor or plan a succession to avoid affecting operations. Bench strength can be a sign of warning regarding the probability of risk that may occur based on the score or rate of achievement displayed. To ensure a stable and strong bench strength, department heads and management should conduct a talent review or talent pool review to identify individuals who not only have potential, but are also capable and interested and understand the values and have existing beliefs in the organization's principles and core values. Furthermore, the career paths and promotion opportunities for the group of individuals involved are provided, so that the employees are aware of all of the management's planning. It has been stated that it is much better to grow out a leader from a company rather than hire one from outside (Pandey \& Sharma, 2014). The difficulty of identifying and preparing such groups of individuals will result in organizations having to look at alternative options by finding suitable external candidates to fill the vacant positions.

\subsection{Time-to-Fill}

Time-to-fill is a measure of the effectiveness of hiring efforts and the hiring process. If an organization makes a succession plan based on hiring outside workers, reducing the time-to-fill is crucial to the success of the plan. In addition, there are measurement indicators based on the period of filling positions, especially from the group within the organization. This is to strengthen the justification for the effectiveness of the succession plan by targeting the positions held among the internal staff of the organization as opposed to the option of hiring external candidates. Time-to-fill is a very different metric from time-to-hire. Time-to-fill captures the time for the entire hiring process from job requisition to job acceptance, while time-to-hire captures the time the eventual hire enters the talent pipeline to the time they accepted an employment offer (SHRM, 2017). Time-to-fill is the total amount of working days between submission of a job requisition to official hire. If the organization is looking to understand time-to-fill on a team, department, or organizational level, add the sums for each role divided by roles hired

\subsection{Talent Turnover}

Succession planning and employee retention are mutually reinforcing, meaning ineffective succession planning leads to turnover, and that would, in turn, make the succession plan ineffective (Hassan \& Siddiqui, 2020). Retention is an early indicator of employee happiness and wellbeing. The organization can set up a superb succession plan process, but it will not solve the issue of the employees leaving. Hence, succession plan metrics also need to look at the percentage of turnover among talent groups. Individuals who leave the organization for any reason, either directly or indirectly, can affect the amount of individual potential for the next line of leadership. Organizations need to anticipate the turnover rate that will occur based on factors that can be controlled, such as the individual retirement period, or always provide facilities and take care of employee welfare with a clearer environment and career 


\section{Al Macrothink}

International Journal of Human Resource Studies

ISSN 2162-3058 2022, Vol. 12, No. 1

opportunities. Ali \& Mehreen (2019) found that succession planning provides job security and creates positive career attitude, which in turn, mitigates the turnover intentions among employees.

Table 4. Success Metric of Succession Planning

\begin{tabular}{|c|c|c|c|}
\hline No & Authors & Success Metric Indicator & Description \\
\hline \multirow[t]{3}{*}{1} & \multirow[t]{3}{*}{$\begin{array}{l}\text { Rothwell } \\
\text { (2016) }\end{array}$} & $\begin{array}{l}\text { How long does it take to fill key } \\
\text { positions? }\end{array}$ & $\begin{array}{l}\text { Measure the average elapsed days per position } \\
\text { vacancy }\end{array}$ \\
\hline & & $\begin{array}{l}\text { Percentage of key positions that are } \\
\text { filled from within? }\end{array}$ & $\begin{array}{l}\text { Divide the number of key positions filled from } \\
\text { within by the total number of key positions }\end{array}$ \\
\hline & & $\begin{array}{l}\text { Percentage of key positions that can } \\
\text { be filled from within? }\end{array}$ & $\begin{array}{l}\text { Divide the number of high-potential workers } \\
\text { available by the number of expected key position } \\
\text { vacancies annually }\end{array}$ \\
\hline \multirow[t]{7}{*}{2} & \multirow{7}{*}{$\begin{array}{l}\text { Pandey \& } \\
\text { Sharma } \\
(2014)\end{array}$} & Fulfilment percentage & Percentage of vacancies filled internally \\
\hline & & Ready pool & $\begin{array}{l}\text { Percentage of position for which ready and willing } \\
\text { successors are identified }\end{array}$ \\
\hline & & $\begin{array}{l}\text { Retention rate of High Potential } \\
\text { (HIPO) }\end{array}$ & Percentage of HIPO retained in the pool \\
\hline & & $\begin{array}{l}\text { Performance of recently } \\
\text { promoted }\end{array}$ & $\begin{array}{l}\text { Number of rating of excellent / } 1 \text { - or exceeds } \\
\text { expectations }\end{array}$ \\
\hline & & $\begin{array}{l}\text { Number of High Potential (HIPO) } \\
\text { promoted }\end{array}$ & No. of HIPO identified and given opportunity. \\
\hline & & No successor & Priority positions with limited or no successors \\
\hline & & Positions covered & $\begin{array}{l}\text { Percentage of positions covered by succession plan } \\
\text { process }\end{array}$ \\
\hline \multirow[t]{4}{*}{3} & \multirow{4}{*}{$\begin{array}{l}\text { Federal } \\
\text { Authority } \\
\text { for Human } \\
\text { Resource } \\
\text { (FAHR), } \\
\text { UAE } \\
(2019)\end{array}$} & Bench strength & $\begin{array}{l}\text { Number of essential resources available in the } \\
\text { talent pool } \\
\text { Number of key positions in total }\end{array}$ \\
\hline & & $\begin{array}{l}\text { Percentage of critical positions with } \\
\text { identified successor }\end{array}$ & $\begin{array}{l}\text { Number of key positions having 'Ready Now' } \\
\text { successor } \\
\text { Number of key positions available in total }\end{array}$ \\
\hline & & $\begin{array}{l}\text { Talent (HIPO) turnover percentage } \\
\text { rate }\end{array}$ & $\begin{array}{l}\text { Number of essential resources that have departed } \\
\text { the organization } \\
\text { Number of resources available in the talent pool }\end{array}$ \\
\hline & & Percentage utilization of talent pool & $\begin{array}{l}\text { Number of essential resources promoted, elevated, } \\
\text { or transferred } \\
\text { Number of essential resources in the talent pool }\end{array}$ \\
\hline
\end{tabular}

\section{Alignment Success Metric of Succession Planning}

The alignment process also includes an evaluation component that must be defined in a clear and consistent manner using a success metric method. Evaluation refers to the level of outcome that will place the success of a process or system according to the standard criteria. 
The success metric is a mechanism to assess the success level of a process, especially in the succession plan. It links the Key Performance Indicator (KPI) of the succession plan with the organization's KPI. Several authors have suggested that succession planning cannot effectively operate in isolation; it has to be integrated into the overall organizational strategy and become part of the culture (Al Suwaidi et al., 2020; Atwood, 2007; Kouzes \& Posner, 2017). indicators.

\section{Discussion}

The effective succession planning needs to be a planned and structured process in order to create a strong pipeline of high-potential talent for the next generation of business leaders (Rothwell, 2016; Atwood, 2007; Calareso, 2013). It is all about getting the basics right, keeping to a high-quality process once it has been established, and building in accountability for closing gaps in the pipeline of potential talent in succession. The success metric is a critical component of evaluation since it serves as a performance indicator for determining how effective succession planning is. The success metric will determine how the succession planning achieves the objective of organization. This study focuses on three key success metrics of succession planning: (1) bench strength, (2) time-to-fill, and (3) talent turnover. Succession planning is seen as a critical approach for managing people and focused on establishing a pool of future leaders in order to secure the organization's ultimate goal. However, in order to respond to demanding and rapidly changing business environment, the concept of succession planning must agile and evolve accordingly. The organization needs to focused on creating succession planning programs that align with their business strategy and changing business needs through the measurement of success metric indicator.

\section{Conclusion}

In conclusion, the three scopes that have been discussed are evolution of succession planning, systematic process, and success metric of succession planning. The scopes discussed are closely related to the effectiveness of succession planning. When these three scopes are combined, succession planning carries a broader meaning in which it is a systematic process toward the preparation of future leaders and individual career development. Systematic succession planning process are indeed given attention in developing individual to be ready leaders for key positions at organization. A rigorous development plan must be implemented through a systematic approach to ensure that the organization's top talents are given relevant exposure and opportunities for growth in order to fully realized their leadership potential.

\section{References}

Abdellah, H. (2021). Managerial Succession Planning for School Principals introduction to organizational development in the light of Rothwell's model. International Journal of Research in Educational Sciences, 4(3), 201-228. https://doi.org/10.29009/ijres.4.3.5

Aboradi, M. S., \& Masari, R. (2018). Small Medium Sized Enterprises in Saudi Arabia: Conceptualizing an Effective Succession Planning. International Journal of Accounting, 3(11), 14-32.

Al Suwaidi, M., Jabeen, F., Stachowicz-Stanusch, A., \& Webb, M. (2020). Determinants Linked to Executive Succession Planning in Public Sector Organizations. Vision, 24(3), 
284-299. https://doi.org/10.1177/0972262920932405

Ali, Z., Mahmood, B., \& Mehreen, A. (2019). Linking succession planning to employee performance: The mediating roles of career development and performance appraisal. Australian Journal of Career Development, 28(2), 112-121. https://doi.org/10.1177/1038416219830419

Ali, Z., \& Mehreen, A. (2019). Understanding succession planning as a combating strategy for turnover intentions. Journal of Advances in Management Research, 16(2), 216-233. https://doi.org/10.1108/JAMR-09-2018-0076

Atwood, C. G. (2007). Succession Planning Basics. Alexandria, VA: Association for Talent Development.

Badawy, T. A. El, Alaadin, Y., \& Magdy, M. M. (2016). Succession planning, job engagement and job satisfaction: the missing link. Middle East J. of Management, 3(1), 1. https://doi.org/10.1504/mejm.2016.077108

Barnes, L. B., \& Hershon, S. A. (1976). Transferring Power in The Family Business. Harvard Business Review. https://hbr.org/1976/07/transferring-power-in-the-family-business

Barr, M. (2019). Strategizing Effective Succession Planning for Information Technology Executives. Dissertation,PHD, Walden University.

Berchelmann, D. K. (2005). Succession Planning. Journal for Quality and Participation, 28(3), 11-12.

Berke, D. (2005). Succession Planning and Management: A Guide to Organizational Systems and Practices. Center for Creative Leadership, Greensboro, NC.

Bogdány, E., Bogdany, Á. B., \& Csizmadia, T. (2014). Leadership succession and the origin of successor in Hungarian SMEs. Management and Marketing, 9(3), 283-300.

Calareso, J. (2013). Succession planning: the key to ensuring leadership: the key is that the process of leadership formation is not random and serendipitous, but rather intentional and well planned. Planning for Higher Education, 4l(3).

Carriere, B. K., Muise, M., Cummings, G., \& Newburn-Cook, C. (2009). Healthcare succession planning: An integrative review. Journal of Nursing Administration, 39(12), 548-555. https://doi.org/10.1097/NNA.0b013e3181c18010

Chang, C. Y., \& Besel, K. (2020). Cultivating next generation of healthcare leaders in Havana: Barriers and recommendation for succession planning. International Journal of Healthcare Management, O(0), 1-9. https://doi.org/10.1080/20479700.2020.1731174

Chavez, B. J. (2011). The Case for Succession. Strategic Finance, February, 15-17.

Conger, J. A., \& Fulmer, R. M. (2004). BUILD A BETTER LEADERSHIP PIPELINE. Center of Effective Organizations, 6(213), 0-49. http://ceo.usc.edu/pdf/T9821349.pdf

Crumpacker, M., \& Crumpacker, J. M. (2007). Succession planning and generational stereotypes: Should HR consider age-based values and attitudes a relevant factor or a passing fad? Public Personnel Management, 36(4), 349-369. https://doi.org/10.1177/009102600703600405

Fahr UAE. (2017). Succession Planning \& Talent Pool Development Framework In The Federal Government.

Garman, A., \& Practice, J. G. (2004). Succession planning. Consulting Psychology Journal:, 56(2), 119-128. https://psycnet.apa.org/record/2004-15301-005

Gersick, K. E., Davis, J. A., Hampton, M. M., \& Ivan Lansberg. (1997). Generation to Generation: Life Cycles of the Family Business. Harvard Business School Press. 
Gordon, G. E., \& Rosen, N. (1981). Critical factors in leadership succession. Organizational

Behavior and Human Performance, 27(2), 227-254. https://doi.org/10.1016/0030-5073(81)90048-9

Greiner, L. E. (1998). Evolution and Revolution as Organizations Grow. Harvard Business Review. https://hbr.org/1998/05/evolution-and-revolution-as-organizations-grow

Groves, K. S. (2007). Integrating leadership development and succession planning best practices. Journal of Management Development, 26(3), 239-260. https://doi.org/10.1108/02621710710732146/FULL/PDF

Grusky, O. (1960). Social Forces. The Journal of Philosophy, 39(2), 105. https://doi.org/10.2307/2022234

Handler, W. C. (1990). Succession in Family Firms: A Mutual Role Adjustment between Entrepreneur and Next-generation Family Members. Entrepreneurship Theory and Practice, 15(1), 37-52. https://doi.org/10.1177/104225879001500105

Hassan, S. N. U., \& Siddiqui, D. A. (2020). Impact of Effective Succession Planning Practices on Employee Retention: Exploring the Mediating Roles. International Journal of Human Resource Studies, 10(2), 21. https://doi.org/10.5296/ijhrs.v10i2.16339

Huang, T. C. (2001). Succession management systems and human resource outcomes. International Journal of Manpower, 736-747. https://doi.org/10.1108/EUM0000000006508

Jackson, N. C., \& Dunn-Jensen, L. M. (2021). Leadership succession planning for today's digital transformation economy: Key factors to build for competency and innovation. Business Horizons.

Kesner, I. F., \& Sebora, T. C. (1994). Executive Succession: Past, Present \& Future. Journal of Management, 20(2), 327-372. https://doi.org/10.1177/014920639402000204

Khanaman, S. A., Hamdollah Manzari Tavakoli, Salajegheh, S., \& Sheikhu, A. (2020). Creation of a strong bond between decision making styles of managers and organization structure through succession planning: a desirable model. Revista Conrado, 16(73), 442-448.

Kohler, T., \& Strauss, G. (1983). Executive succession: Literature review and research issues. Administration in Mental Health, 11(1), 11-22. https://doi.org/10.1007/BF00843168

Kouzes, J. M., \& Posner, B. Z. (2017). The leadership challenge: How to make extraordinary things happen in organizations (6th Editio). Hoboken, NJ: John Wiley and Sons.

Longenecker, J. G., \& Schoen, J. D. I. (1978). Management Succession in the Family Business. Journal of Small Business Management, 16, 1-8.

Morrin. (2013). Factors that are Important to Succession Planning: A Case Study of One Ontario College of Applied Arts and Technology. College Quarterly, 16(1), 22.

Orellano, T., \& Miller, J. (1997). Succession planning: Lessons from Kermit the frog.

Pandey, S., \& Sharma, D. (2014). Succession Planning Practices and Challenges: Study of Indian Organisations. Procedia Economics and Finance, 11(14), 152-165. https://doi.org/10.1016/s2212-5671(14)00185-3

Parfitt, C. (2017). Creating a Succession-Planning Instrument for Educational Leadership. Education Leadership Review, 18(1), 21-36.

Riddick, F. P. (2009). What is Your Bench Strength? An Exploration of Succession Planning in Three Large School Districts in a Southeastern State (N. C. Raleigh (ed.)). Dissertation,PHD.

Rothwell, W. J. (2005). Effective succession planning: ensure leadership continuity and 
building talent from within. American Management Association, New York.

Rothwell, W. J. (2016). Effective succession planning: ensure leadership continuity and building talent from within (5th Editio). American Management Association.

SHRM. (2017). Time-to-Hire/Time-to-Fill Calculation Spreadsheet. Society for Human Resource Management (SHRM). https://www.shrm.org/resourcesandtools/tools-and-samples/hr-forms/pages/time-to-hire---tim e-to-fill-calculation-spreadsheet.aspx

Song, J. H., \& Thompson, L. (2011). Measuring the Value of Succession Planning and Management: A Qualitative Study of Multinational Companies. 24(3), 55-76. https://doi.org/10.1002/piq

Weisblat, I. A. (2018). Literature review of succession planning strategies and tactics. Succession Planning: Promoting Organizational Sustainability, 11-22. https://doi.org/10.1007/978-3-319-72532-1_2

\section{Copyright Disclaimer}

Copyright for this article is retained by the author(s), with first publication rights granted to the journal.

This is an open-access article distributed under the terms and conditions of the Creative Commons Attribution license (http://creativecommons.org/licenses/by/4.0/). 